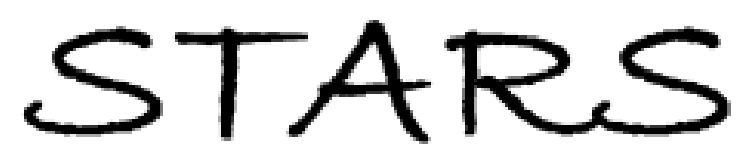

University of Central Florida

STARS

\title{
The role of tourism in poverty reduction: An empirical assessment
}

Robertico Croes

University of Central Florida, robertico.croes@ucf.edu

Part of the Hospitality Administration and Management Commons, and the Tourism and Travel Commons

Find similar works at: https://stars.library.ucf.edu/rosenscholar

University of Central Florida Libraries http://library.ucf.edu

This Paper is brought to you for free and open access by the Rosen College of Hospitality Management at STARS. It has been accepted for inclusion in Rosen Faculty Scholarship and Creative Works by an authorized administrator of STARS. For more information, please contact STARS@ucf.edu.

\section{Original Citation}

Croes, R. (2014). The role of tourism in poverty reduction: An empirical assessment. Tourism Economics, 20(2), 207-226.

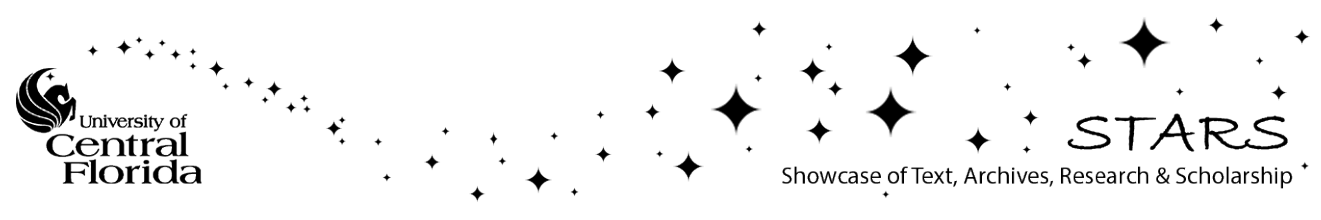




\title{
The role of tourism in poverty reduction: an empirical assessment
}

\author{
ROBERTICO CROES \\ Tourism, Events and Attractions, Rosen College of Hospitality Management, University of \\ Central Florida, 9907 Universal Blvd, Orlando, FL 32819, USA. E-mail: \\ robertico.croes@ucf.edu.
}

\begin{abstract}
This paper assesses how tourism affects absolute poverty beyond its effects on growth in two developing countries. In particular, the author explores whether tourism spending leads to a decline in the proportion of people below the poverty line. An error correction model is applied to estimate the relationship between poverty and tourism spending. The results reveal that tourism does matter for the poor, but that it does not appear to have systematic effects, and that tourism development matters most for the poor at the lower levels of economic development. The findings from the two developing country case studies show differing impacts of tourism development, and thus the policy implications differ for each case.
\end{abstract}

Keywords: error correction model; cointegration; Granger causality; poverty relief; Kaldorian approach; Central America

The endless debate on poverty reduction strategies hinges partly on whether tourism contributes to the decrease in poverty in developing countries. Tourism has become an important economic activity for many developing countries in their search to lessen poverty and increase prosperity (Clancy, 1999; Hawkins and Mann, 2007; Croes and Vanegas, 2008). The tourism-led growth (TLG) strategy remains the main reason for developing countries to allocate resources to tourism. The TLG asserts that tourism creates jobs and income, leads to positive balance of payments, stimulates tourism related business and results in increased economic activity. There is enough empirical evidence suggesting a strong positive correlation between tourism development and economic growth (Belisle and Hoy, 1980; West, 1993; Modeste, 1995; Zhou et al, 1997; Shan and Wilson, 2001; Sandler, 2001; WTO, 2002; Sugiyarto 2007; Easterly, 2002; Balaguer and Cantavella-Jorda, 2002; Dwyer et al, 2003; Dritsakis, 2004; Durbarry, 2004; Eugenio-Martin et al, 2004; Brau et al, 2005; Kim et al, 2006; Croes and Vanegas, 2008). Sinclair and Stabler (1997) assert that an injection of tourist revenues into developing countries could have significant impact on their economies.

Despite the significant amount of tourism research, there is little understanding of what impact tourism has on the poor in developing countries. The lack 
of understanding is a serious issue, because one-quarter of the world's population is mired in poverty. International organizations, such as the World Tourism Organization (WTO), have identified tourism as a key driver to combat poverty. Many developing countries have adopted tourism as an important development tool in their strategies to lessen poverty. Mitchell and Ashley (2010) assert that $80 \%$ of poverty reduction documents in Africa reference tourism. Empirical evidence supporting this assertion is lacking or weak. Despite this situation, poverty issues have percolated to the heart of the development debate. The global community has identified halving the poor in the world as a priority development goal in 2015, through the First Millennium Development Goal (MDG).

Tourism studies have remained silent on the issue of tourism development and poverty reduction because of the strong tradition in the trickle-down theory. Efficiency is the most daunting challenge facing a country and the market guides resources to their most efficient use. Efficiency therefore provides for social optimality and is the source of economic growth. The benefits from growth will diffuse to society as a whole working for the poor, according to this view. Mak (2004), for example, argued to distinguish the notion of efficiency from equity: an action that might improve everyone's well-being may strengthen some people's welfare more than others. If those who benefited from this efficiency are the richest, then improved efficiency might be consistent with more inequality. This would be unacceptable because of the persisting poverty in the world.

The mixed experience of developing countries in applying the TLG strategies suggests serious gaps in the existing research. Consider the following questions. Have some countries experienced higher rates of poverty at comparable levels of tourism revenues? Do trends in some countries warrant a closer examination of the types of policies that may be effectively replicated (or avoided) elsewhere? Or, in general, why has tourism failed to reduce poverty in all developing countries?

The purpose of this study is to investigate the empirical relationship between tourism and poverty relief in two developing countries. This study investigates whether an empirical relationship between tourism and poverty reduction exists and measures the specific effects on poverty decline. Specifically, the study attempts to answer three interrelated questions. First, is there a relationship between tourism development and poverty decline? Second, if there is a relationship, what is the nature of that relationship? Third, what is the direction of the relationship? This paper examines the relationship between tourism and absolute poverty, rather than relative poverty, which refers to income distribution. The study defines the construct of poverty as the inability to consume a minimum bundle of goods and is measured by a minimum monetary income. One dollar per day per person refers to absolute poverty while US $\$ 2$ per day per person refers to moderate poverty (Chen and Ravallion, 2001).

The study employs the Kaldorian approach, which asserts that foreign demand is the promoter of economic growth, and that growth reduces poverty. It applies an error correction model (ECM) to estimate and assess the empirical relationship between tourism and poverty reduction in two developing countries in Central America. The application of ECM in tourism studies has been sporadic and limited to tourism demand studies (Song et al, 2009) and more 
recently to tourism and economic growth (Balaguer and Cantavella-Jorda, 2002; Dritsakis, 2004; Durbarry, 2004; Katircioglu, 2009). The study specifically considers the Central American countries of Costa Rica and Nicaragua (among the poorest regions of the world) as case studies. While the use of an econometric case study design might not possess an external validity, it could discern valuable data patterns, thus facilitating inferential analysis. The development trajectory of both countries has achieved different results in addressing poverty. The application of ECM may provide an understanding of the short- and longterm effects of development adjustment, which in turn may make crucial policy information and strategies available to relieve poverty.

\section{A snapshot of current poverty}

Poverty represents itself as poor health and inaccessibility to good medical facilities, illiteracy, irregular income, informal employment, multiple occupations, lack of land tenure for housing, lack of basic infrastructure quality, disempowerment and personal insecurity. The poor seem vulnerable to health crises, earthquakes, hurricanes, crime, unemployment and droughts. About 1.5 billion people do not have access to clean water; about 2 billion do not have access to electricity (Arvin and Barillas, 2002). The aggravating gap that separates rich nations from poor nations is the central economic and social concern of our time. For example, the poorest $20 \%$ of the world's population accounts for $1.5 \%$ of the world's private consumption; and the richest $20 \%$ consume an astonishing 77\% (World Bank, 2009). Within developing countries, the imbalance of the consumption of the rich and poor is also appalling. In Brazil, for example, the richest $10 \%$ consumes $50 \%$ of the economy, while the poorest $50 \%$ of the country only consumes $10 \%$ of the economy. Consequently, about 25,000 people die every day of hunger, while a new billionaire is created every second day (Sachs, 2005).

Traditionally, the definition of 'poor' has been based on household financial income or expenditure. This definition reflects the inability of individuals to afford a minimum provision of goods and services that ensure their well-being. Household surveys are a tool that allow for the measurement of income or real consumption. Deaton (2002) suggests there is a surplus of literature on the various conceptual and applied issues that dominate the measurement of poverty through survey data. A vital conceptual consideration, though, is how the poverty line is actually to be determined. One of the main authors to provide an overview of the theory and methods in looking at this issue is Ravallion (2001). He makes a difference between absolute poverty and relative poverty and suggests that the poor can be defined as those whose resources fall under a particular line, or threshold at the initial date $t-1$. Poverty may also be defined in relative terms as a specific percentage of the mean or median income of the whole population or the distribution of income of the population (Bourguignon, 2006). The former definition is used in this study.

Additionally, the literature questions how the poverty line is measured. Most organizations, such as the World Bank, use the poverty headcount index as a common practice. For example, the World Bank bases its estimation of the poor on a fabricated poor line of US $\$ 1$ a day income. Those below this line would be considered extremely poor. This metric is grounded in the study by Chen 
and Ravallion (2001) who compared household survey data in 1997 of 158 lowand middle-income countries. Problems of comparability across different survey instruments remain (Deaton, 2002). The idea of a poverty line, whether based income or on consumption criteria, could be criticized. But the advantages of a line separating the 'poor' from the 'non-poor' are considerable. By this account, for example, in Latin America and the Caribbean, this amount has increased from 48 million in 1990 to 56 million in 2004: one in every six people in Latin America lives in extreme poverty; 136 million people live with less than two dollars per day per person. In other words, one in every four people lives in moderate poverty conditions (ECLAC, 2007). Table 1 provides estimates of the number of people living below the poverty line worldwide.

There are enormous consequences for the global economy as much productivity is wasted because of poverty, thereby robbing millions of an opportunity for a better quality of life. Consider this reality: 799 million people, or $17 \%$ of the developing countries, are undernourished; every day 25,000 children starve to death (UNICEF, 2008); more than 20,000 people die every day because of extreme poverty - up to 8,000 from malaria, 5,000 from tuberculosis, 7,500 young adults from AIDS, and thousands more of diarrhoea, respiratory infections exacerbated by bodies weakened by hunger (Sachs, 2005). The poor consume about one-half of the average food calories needed per day (Banerjee and Duflo, 2007).

The abysmal situation of the poor has wasted significant resources. De Soto (2000) claimed that the poor in the developing world, because they are excluded from certain social arrangements, such as private property, cannot use their assets as collateral to raise capital and hence are also excluded from crucial credit opportunities. They are denied economic facilities in the form of opportunities for participation in trade and production. According to De Soto (2000), about US\$9 trillion of property (not legally owned) is wasted - terming it 'dead capital'. The question is, can tourism help the poor?

\section{Tourism and poverty reduction}

Tourism has been an important component of the economic development strategies of developing countries since the 1960s. International organizations have identified tourism as an engine of growth to assist poor countries in reducing poverty (WTO, 2002; Hawkins and Mann, 2007). The WTO (2002), for example, argues that tourism, with the requisite of travel to a destination, is a sector inductive to poverty reduction. When tourism is used as a growth engine to assist in poverty reduction, there may be several advantages over other forms of economic stimuli. This is because the tourist consumes a bundle of services and non-traded goods locally from more than one supplier. Thus, many different service suppliers participate in creating a tourism experience. This could create the opportunity for poor, marginal and remote areas to benefit from the advantages (increased employment opportunities, higher income levels and a trickle-down effect) that tourism spending may bring to a destination.

In the past few decades, tourism has been growing faster in developing countries than elsewhere; tourism's share in the economies of developing countries has increased; and many of the countries engaged with tourism are among the poorest and least developed countries. For example, of the 78 low-income 


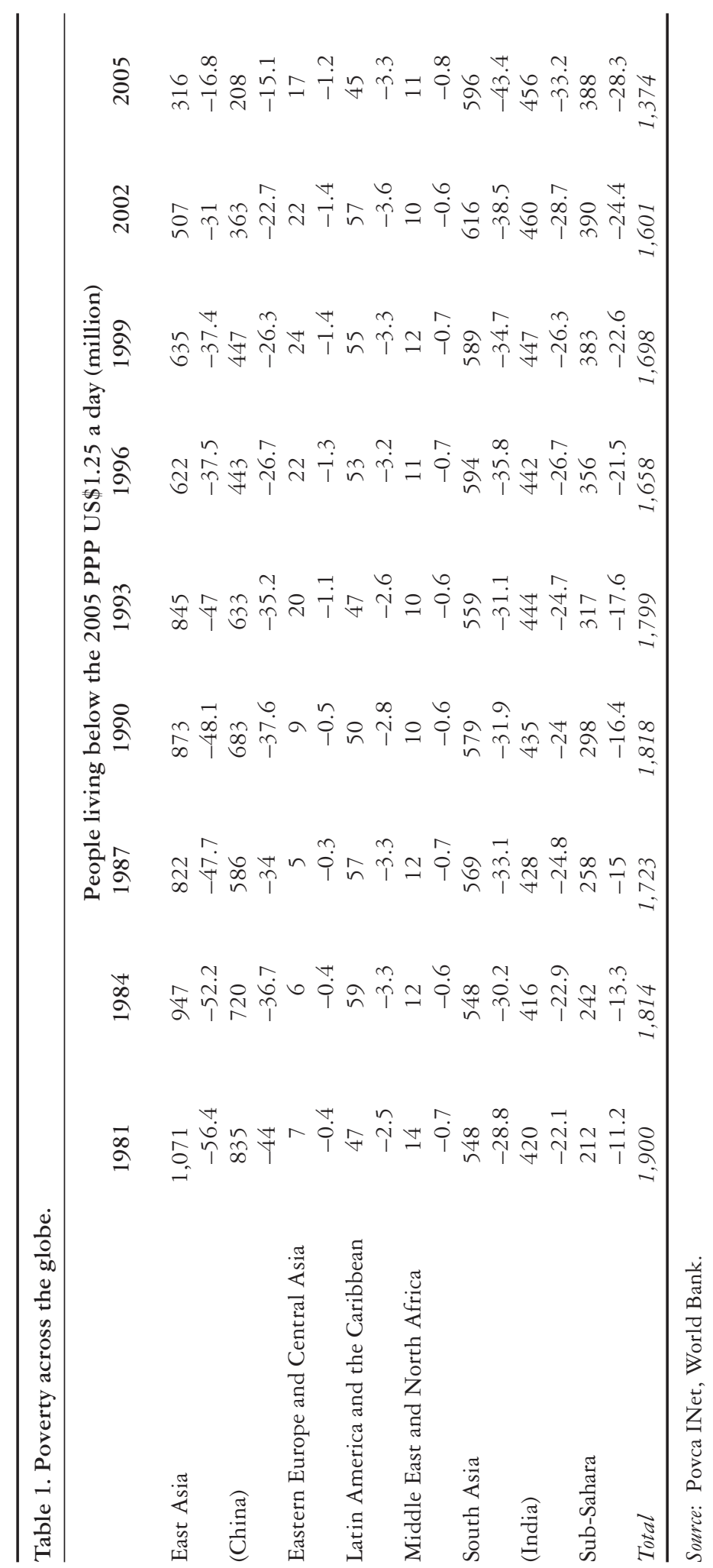


Table 2. Poverty and tourism ratios in selected developing countries.

$\begin{array}{cccc}\begin{array}{c}\text { Poverty } \\ \text { headcounts in }\end{array} & \begin{array}{c}\text { Tourism receipts } \\ \text { as } \% \text { exports }\end{array} & \begin{array}{c}\text { Tourism receipts } \\ \text { as } \% \text { of GDP }\end{array} & \begin{array}{c}\text { Year } \\ \text { poverty data }\end{array} \\ \% \text { (U day) } & & & \end{array}$

\begin{tabular}{|c|c|c|c|c|}
\hline \multicolumn{5}{|l|}{ Africa } \\
\hline Burkina Faso & 56.54 & 9.6 & 0.9 & 2003 \\
\hline Ethiopia & 39.04 & 24.5 & 4.3 & 2005 \\
\hline Madagascar & 67.83 & 8.6 & 1.4 & 2005 \\
\hline Malawi & 73.86 & 9.4 & 2.5 & 2004 \\
\hline Mali & 51.43 & 10.1 & 3.1 & 2006 \\
\hline Uganda & 51.53 & 25.8 & 3.5 & 2005 \\
\hline $\begin{array}{l}\text { United Rep of } \\
\text { Tanzania }\end{array}$ & 88.52 & 28.1 & 4.5 & 2000 \\
\hline Zambia & 64.29 & 11.2 & 3.4 & 2004 \\
\hline \multicolumn{5}{|l|}{ Latin Americab } \\
\hline Haiti & 54.9 & & & 2001 \\
\hline Nicaragua & 45.06 & 11.9 & 3.8 & 2001 \\
\hline Bolivia & 19.62 & 9.4 & 2.2 & 2005 \\
\hline El Salvador & 20.44 & 12.9 & 3.5 & 2002 \\
\hline Guatemala & 13.97 & 15.7 & 2.6 & 2002 \\
\hline Honduras & 14.05 & 12.8 & 4.9 & 2003 \\
\hline Paraguay & 16.37 & 2.8 & 1.3 & 2002 \\
\hline Peru & 12.83 & 9 & 1.6 & 2002 \\
\hline Costa Rica $^{c}$ & 2.37 & 16.9 & 7.3 & 2005 \\
\hline $\begin{array}{l}\text { Dominican } \\
\text { Republic }^{c}\end{array}$ & 3.96 & 37.7 & 17.1 & 2006 \\
\hline \multicolumn{5}{|l|}{ Others $^{\mathrm{d}}$} \\
\hline Bangladesh & 36.03 & 0.7 & 0.1 & 2000 \\
\hline Lao & 27.37 & 18.4 & 5.9 & 2002 \\
\hline Nepal & 25.27 & 21.8 & 4 & 2003 \\
\hline
\end{tabular}

Notes: ${ }^{a}$ The table includes countries with a poverty headcount of greater than $20 \%$ and with data availability from 2000 to the present. ${ }^{\mathrm{b} C}$ Countries included are those with a poverty headcount greater than $10 \%$ and data availability from 2000 to the present. 'Costa Rica and the Dominican Republic are included as a matter of comparison. ${ }^{\mathrm{d} C o u n t r i e s ~ i n c l u d e d ~ a r e ~ t h o s e ~ w i t h ~ a ~ h e a d c o u n t ~ o f ~} 20 \%$ or more and data availability from 2000 to the present.

Source: World Bank (2009) and WTO (2002).

countries (per capita gross domestic product (GDP) of less than US\$760), 56 designed a poverty reduction strategy. Forty-five of the 56 group identified tourism as a major catalyst of poverty reduction (Hawkins and Mann, 2007). It appears that considerable resources are allocated to tourism to harness the benefits that tourism could bring. Yet, Sinclair (1998) claims, in some countries where tourism generates foreign exchange, tourism receipts did not reduce poverty. It may be that leakages through imports were significant in these countries, thereby offsetting potential tourism benefits. Table 2 indicates the level of importance of tourism receipts in the economy and the poverty headcounts (percentage of population under US $\$ 1$ per day) in selected countries. The link between tourism receipts and poverty is not straightforward.

For example, Nicaragua (the country considered in detail in this study) has 
a lower level of tourism earnings relative to GDP than Honduras, about the same as El Salvador, and one-half of that of Costa Rica (another case study in this investigation). Tourism plays an important role in Costa Rica and the Dominican Republic, two countries that have been successful in overcoming poverty challenges in Latin America. The key challenge appears to be, then, how to ensure that the benefits of tourism development accrue to the poor.

\section{Background}

While tourism and poverty reduction have been linked since the 1960s, the search to establish an empirical link between the two has been very recent. The search can be classified in two strands: the first refers to the establishment of an empirical link between tourism and economic growth and is grounded in the debate of the tourism-led growth hypothesis. It asserts that tourism is growth oriented and implicitly assumes that growth will trickle down to the poor. The second refers to the attempt to establish a direct empirical link between tourism and poverty reduction.

The first strand contains country-specific and cross-section studies. In the country-specific studies, Ghali (1976) measured the contribution of tourism growth to the growth of income in the case of Hawaii and found that tourism had generated significant growth. Balaguer and Cantavella-Jorda (2002) examined the contribution of tourism in Spain and found that tourism led to significant economic growth. Durbarry (2004), Dritsakis (2004) and Narayan (2004) found similar results in Mauritius, Greece and Fiji.

Hazari and Sgro (1995) built a dynamic model and claimed that tourism spending would have a positive impact on the long-run growth of a small economy. They posited that tourism demand altered the consumption pattern of the locals by allowing them to consume now rather than later by requiring a lower savings rate. Using Lucas's (1988) two-sector endogenous growth model, Lanza and Pigliaru (2000) examined the tourist specialization of a small country and its effects on economic growth. They indicate that tourism appears as growth enhancing irrespective of the size of the country. Brau et al (2003) compared the growth performance of 143 countries concluding that countries more specialized in tourism tend to grow faster than non-specialist countries. Croes and Vanegas (2008) also found a positive significant relationship between tourism spending and economic growth for Nicaragua. Sequeira and Nunes (2008) found a positive correlation between tourism receipts and growth rate, especially for tourist specialist countries.

In contrast, Hazari et al (2003) used a Generalized Harris Todaro model assessing the impact of tourism spending in rural and urban areas and concluded that this spending could lead to immizerization in the rural area and could put urban and rural citizens' interests at odds with each other. Eugenio-Martin et al (2004) found that tourism was not universally growth-conducive in Latin America. They found that only in medium and low-income countries was tourism likely to generate growth. Oh (2005), in a case study of Korea, used the TLG hypothesis to identify a strong positive relationship between growth to tourism rather than tourism as a catalyst for growth. Nowak and Sahli (2007) found that tourism spending could lead to welfare losses when tourism products 
are intensive users of coastal areas. Capo et al (2007), in examining the cases of the Balearics and Canary Islands (tourism dependent islands), found symptoms of Dutch Disease rendering the sustainability of these islands as untenable in the future. And Katircioglu (2009) rejected the TLG hypothesis for Turkey based on an ECM analysis.

Of the studies concerned with the TLG hypothesis, only one tested the specific empirical relationship between tourism and poverty reduction (Croes and Vanegas, 2008). All other studies assume that growth will trickle down to the poor. Croes and Vanegas (2008) applied a vector autoregressive approach in assessing the role of tourism in poverty reduction in Nicaragua. They found a significant positive relationship between the two variables. Blake et al (2008) used a computable general equilibrium (CGE) model to assess the contribution of tourism on poverty reduction in Brazil. They found that tourism benefits the lowest income households albeit to a lesser extent than higher income groups.

The preceding studies justify including tourism in a growth model to test the relationship of growth to poverty reduction. The TLG hypothesis does not seem, however, to be universally applicable. In addition, there is a clear dearth in the search for a more direct empirical relationship between tourism and poverty reduction. The studies that were conducted in this regard appear to be limited in terms of the applied methodologies. The vector autoregression (VAR) technique used by Croes and Vanegas (2008) provides a cogent tool for assessing the long-run relationship but cannot provide insights into the shortterm adjustment trajectory of countries. In addition, the study lacks a theoretical foundation in assessing the link between tourism and poverty reduction.

The CGE model used by, for example, Blake et al (2008) is premised on the general equilibrium postulates of no friction in the market and the existence of complete feedback. These core assumptions have been contentious in the literature. The attempt to explain empirical regularities in tourism through the general equilibrium model may be hinged on unrealistic assumptions about the tourism market. The market, for example, seems to be riddled by imperfections and distortions generated by externalities and public goods thereby rendering general equilibrium representations as problematic. Distorted and inefficient markets seem to put a disproportionate burden on the poor.

\section{Methodology}

The model departs from the Kaldorian approach, which claims that foreign demand is a promoter of economic growth. According to Kaldor $(1964,1970)$, the growth rate of exports determines the rate of output of growth. Following the principle of parsimony, the study only focuses on the relationship exports and economic growth, and in particular tourism as an export for economic growth. This study focuses on the links between tourism and economic growth because changes in average income will mostly result in changes in poverty. Growth from tourism may benefit the poor directly or indirectly. Poverty in this study is defined in terms of the inability to meet a minimum income threshold of US $\$ 1$ per day per person (generally referred to as the 'headcount').

Following Kaldor's proposition, the formula may be written as: 


$$
y=\gamma x
$$

where $y$ is the $\log$ of real output and $x$ is the $\log$ of export, hence $\gamma$ is the longrun elasticity of output to exports. The TLG hypothesis postulates that countries should allocate resources to tourism which in turn generates employment and income, leads to positive balance of payments, stimulates the supplying sectors of tourism, and results in a generally increased level of economic activity. The notation may be written as:

$$
y=\gamma(t-n t)
$$

where $t$ is the share of tourism in total output and $n t$ represents the non tourism export sector.

There is general consensus that economic growth is an important factor in reducing poverty in addition to the rate of growth itself. We could formulate the impact of economic growth on poverty as:

$$
d P=\alpha+\beta \dot{y}+\varepsilon,
$$

where $P$ is the level of poverty rate and $d P$ is the change in poverty rate; $\dot{y}$ denotes the rate of economic growth, $\varepsilon$ is the error term, while $\alpha$ and $\beta$ are the parameters. Eqation (3) can be rewritten as:

$$
d P=\lambda_{1} t \dot{y}+\lambda_{2} n t \dot{y}
$$

where $\lambda$ is the elasticity of the poverty with respect to the share of the two sectors to GDP; $\dot{y}$ is the growth rate of real GDP in sector $k=t, n t$. From Equation (4) it is clear that the impact of the tourism sector on poverty depends on how its pace of growth performs compared with the other sectors. We are therefore interested in parameter $\lambda_{1}$ in this model, which shows the percentage change in the poverty rate due to a $1 \%$ growth in the tourism share to the GDP. We applied this model and developed it into the following equation:

$$
d P=\alpha^{1} \dot{y}+\alpha^{2} d T+\alpha^{3} t+\alpha^{4} d t+\alpha^{5} d N T+\alpha^{6} d n t+\varepsilon^{t},
$$

where $d T$ stands for total tourism growth, $t$ for total tourism share of GDP, $d t$ for total tourism share growth, NT denotes export share of GDP, and $d N T$ denotes export share growth. Our dependent variable in this analysis is the first difference of the poverty headcount. We expect that the independent variables are unit roots and hence our model would be a differenced series. The longrun relationship may not completely be explained in Equation (5) because of the potential presence of the first difference form of the variables. However, their linear combination could render stationarity. If this is the case then the variables have a long run relationship, or they are cointegrated. We include the error term of Equation (5) to connect the short-term and the long-term effects of the relationship between poverty, economic growth and tourism development. The error term becomes another independent variable, $\left(E C_{t-1}\right)$. The error correction term is the one-period lagged value of the residual from the OLS level regression. 
To test for integration, each variable should be examined based on the following auxiliary equation:

$$
\Delta y^{t}=\alpha+p y^{t-1}+\beta t+\Sigma \tau^{t} \Delta y^{t-1}+\mu^{t},
$$

where $y^{t}$ is the relevant time series variable, $t$ is a linear deterministic trend and $\mu^{t}$ is an error term with a mean of zero and a variance that is constant. If a cointegration relationship can be found, the study will proceed to undertake the estimations in an ECM framework. If a group of variables is I(1) and cointegrated, then regressing one on the others should generate residuals that are $\mathrm{I}(0)$. The error correction framework enables us to combine long run information with short run adjustments (Mukherjee et al, 1998). Finally, the Granger causality test is carried out through the error correction mechanism. The long-run relationships are revealed through data in levels, while short-run behaviours are displayed by relationships in first differences (Engle and Granger, 1987).

The error correction mechanisms have two important outcomes: first, they provide information regarding the direction of causality; and second, they distinguish between short-run and long-run causality. The $F$-test and the explanatory variables indicate the short-run causal effects, while the $t$-test of the lagged ECT reveals the long run causal effect. The Akaike information criteria and the Schwarz Bayesian information criteria were used to make the choice about the number of lags to be introduced in the causality test.

\section{Data}

For the purpose of this study, a case study approach is employed to generalize theoretical proposition and does not contain a sample to make statistical generalization (Yin, 1994). Lijphart (1975) and George (1979) suggested that a comparative case study approach adds rigor to the scientific investigation process. The process features two main conditions: (a) cases should entertain the same goals (for example, the application of tourism as a development strategy; but (b) the cases should manifest different characteristics in other aspects (dissimilar stage in the tourism life cycle).

The study selected Nicaragua and Costa Rica as case studies for these reasons. Costa Rica is the destination in Central America with the largest amount of international arrivals, while Nicaragua has witnessed the largest increase in tourist arrivals in the last decade. The level of extreme poverty in Nicaragua hovers around $45 \%$, while the same level in Costa Rica is less than $10 \%$. Nicaragua is characterized by low incomes and high external debt compared to Costa Rica and the former is on the World Bank and International Monetary Fund list of highly indebted poor countries. Costa Rica had a GDP per capita of US $\$ 5,173$ in 2006 , while Nicaragua had a GDP per capita of only US $\$ 896$ in that same year.

The data employed annual observation expressed in natural logarithms and spans the time period 1980 to 2010. The base period is $100=2000$ prices. The data have been drawn from the Banco Central de Nicaragua/Central Bank of Nicaragua as well as from the World Bank (http://www.worldbank.org/ research/povmonitor/). The annual data for Costa Rica were drawn from the 
Central Bank of Costa Rica and the World Development Indicators from the World Bank and the WTO. The study used a poverty line of a 2005 purchasing power parity adjusted dollar a day line to measure poverty.

\section{Results}

Augmented Dickey-Fuller (ADF) (1979, 1981) and Phillips-Perron (PP) (1988) tests were used to determine the presence of unit roots in the data sets. The ADF test considers several regression equations (autoregressive process of order n) to test for the presence of unit root. The difference between the equations concerns the presence of a deterministic element: drift and linear trend. Two information criteria (Akaike and Schwarz Bayesian) were used to remove any serial correlation in the residuals thereby avoiding a Type I error of rejecting the unit root tests' null hypothesis. The PP test, on the other hand, suggests a non-parametric method for controlling for higher order of autocorrelation in a series. This test is based on a first order autoregressive (AR(1)) process. The non-parametric correction is made to the values $t$-ratio to account for the autocorrelation in the residuals.

The STATA version 11 software package, which is used to conduct the ADF and PP tests, reports the simulated critical values. Tables 3 and 4 present the results of the ADF and PP tests of the variables for Nicaragua and Costa Rica. The results indicate that all the variables are non-stationary at levels. The results also reveal that the first differenced time series attain stationarity; hence, the variables are integrated of order one, I(1). If the variables are cointegrated there should be a long-run relationship that prevents them from drifting apart. To investigate the cointegration relationship, the study applied the Johansen and Juselius (1990) test, based on a trace test and max-eigenvalue test. Tables 5 and 6 report

Table 3. Augmented Dickey-Fuller (ADF) unit root test results.

\begin{tabular}{|c|c|}
\hline Constant without trend & Constant with trend \\
\hline Levels $\quad 1$ st difference & 1st difference \\
\hline
\end{tabular}

\begin{tabular}{lllll} 
Nicaragua & & & & \\
LPOV & $-2.063[2]$ & $-3.891[1]^{*}$ & $-1.559[2]$ & $-4.714[1]^{*}$ \\
LGDP & $-0.299[2]$ & $-3.468[1]^{* *}$ & $-2.803[2]$ & $-4.408[1]^{*}$ \\
LSTGDP & $-2.458[2]$ & $-4.472[1]^{*}$ & $-3.346[2]$ & $-4.879[1]^{*}$ \\
LNTSGDP & $1.301[1]$ & $-3.181[1]^{* *}$ & $-2.549[1]$ & $-4.099[1]^{*}$ \\
Costa Rica & & & & \\
LPOV & $-2.763[2]$ & $-3.540[1]^{*}$ & $-3.307[2]$ & $-3.774[1]^{* *}$ \\
LGDP & $0.307[2]$ & $-3.532[1]^{*}$ & $-3.199[2]$ & $-3.382[1]^{* *}$ \\
LSTGDP & $-1.833[3]$ & $-6.102[1]^{*}$ & $-1.558[3]$ & $-8.199[1]^{*}$ \\
LNTGDP & $-.0911[3]$ & $-4.579[1]^{*}$ & $-2.182[3]$ & $-4.521[1]^{*}$ \\
\hline
\end{tabular}

Notes: The optimal lag length, presented in brackets, for the unit root tests was based on the SIC and AIC criteria. ${ }^{*}$ and ${ }^{* *}$ indicate significance at $1 \%$ and $5 \%$ levels, respectively. The reported critical values of the ADF statistic for levels at $1 \%$ and $5 \%$ are -3.750 and -3.000 , respectively. Critical values of the ADF statistic for first difference at $1 \%$ and $5 \%$ significance are -4.380 and -3.600 , respectively. The critical values are obtained from STATA version 11 and correspond to 25 observations. 


\begin{tabular}{|c|c|c|c|c|}
\hline & \multicolumn{2}{|c|}{ Constant without trend } & \multicolumn{2}{|c|}{ Constant with trend } \\
\hline & Levels & 1st difference & Levels & 1st difference \\
\hline \multicolumn{5}{|l|}{ Nicaragua } \\
\hline LPOV & $-1.890[2]$ & $-3.992[1]^{*}$ & $-1.071[2]$ & $-4.716[1]^{*}$ \\
\hline LGDP & $0.592[1]$ & $-3.585[1]^{* *}$ & $0.965[1]$ & $-4.402[1]^{*}$ \\
\hline LSTGDP & $-2.711[3]$ & $-4.574[1]^{*}$ & $-2.515[3]$ & $-4.924[1]^{*}$ \\
\hline LNTSGDP & $1.454[3]$ & $-4.692[1]^{*}$ & $-1.728[3]$ & $-5.708[1]^{*}$ \\
\hline \multicolumn{5}{|l|}{ Costa Rica } \\
\hline LPOV & $-2.852[2]$ & $-4.127[1]^{*}$ & $-2.789[2]$ & $-4.670[1]^{*}$ \\
\hline LGDP & $0.792[2]$ & $-3.382[2]^{* *}$ & $-2.789[2]$ & $-3.532[2]^{*}$ \\
\hline LSTGDP & $-1.855[3]$ & $-4.992[1]^{*}$ & $-1.799[3]$ & $-5.504[1]^{*}$ \\
\hline LNTSGDP & $-1.032[3]$ & $-3.775[1]^{*}$ & $-1.868[3]$ & $-3.717[1]^{* *}$ \\
\hline
\end{tabular}

Notes: The numbers within brackets followed by PP statistics represent the bandwidth selected based on Newey-West method using Bartlett Kernel. * and ${ }^{* *}$ indicate significance at $1 \%$ and $5 \%$ levels, respectively.

Table 5. Johansen-Juselius test for cointegration: Nicaragua.

\begin{tabular}{llll}
\hline Null & Alternative & Statistic & 95\% critical value \\
Trace statistic & $r \geq 1$ & & \\
$r=0^{*}$ & $r \geq 2$ & 67.8297 & 47.21 \\
$r \leq 1^{*}$ & $r=3$ & 35.945 & 29.68 \\
$r \leq 2$ & & 12.0824 & 15.41 \\
Maximum eigenvalues & $r=1$ & & 27.07 \\
$r=0^{*}$ & $r=2$ & 31.8847 & 20.97 \\
$r \leq 1^{*}$ & $r=3$ & 23.8626 & 14.07 \\
$r \leq 2$ & 10.0159 & \\
\hline
\end{tabular}

Unrestricted Cointegration Rank Test. Maximum lag in Var $=3$.

List of eigenvalues in descending order: 0.706630 .600600 .31970

Notes: $r$ indicates the number of cointegrating relationships. Trace test and maximum eigenvalues indicate 1 cointegrating equation at the 0.05 level. *Denotes the hypothesis at the 0.05 level.

Table 6. Johansen-Juselius test for cointegration: Costa Rica.

\begin{tabular}{lcrc}
\hline Null & Alternative & Statistic & 95\% critical value \\
Trace statistic & & & \\
$r=0^{*}$ & $r \geq 1$ & 104.7923 & 47.27 \\
$r \leq 1^{*}$ & $r \geq 2$ & 56.4209 & 29.68 \\
$r \leq 2^{*}$ & $r=3$ & 5.7213 & 3.76 \\
Maximum eigenvalues & $r=1$ & & 27.07 \\
$r=0^{*}$ & $r=2$ & 48.3714 & 20.97 \\
$r \leq 1^{*}$ & $r=3$ & 32.7287 & 3.76 \\
$r \leq 2^{*}$ & 5.7213 & \\
\hline
\end{tabular}

Unrestricted Cointegration Rank Test. Maximum lag in Var $=3$

List of eigenvalues in descending order: 0.978870 .575330 .457720 .16241

Notes: $r$ indicates the number of cointegrating relationships. Trace test and maximum eigenvalues indicate 2 cointegrating equations at the 0.05 level. ${ }^{*}$ Denotes the hypothesis at the 0.05 level. 
the results indicating that there are at least one cointegrating vector in the case of Nicaragua and three in the case of Costa Rica.

The next step was to estimate the cointegrating regressions for each case and test the residuals for stationarity. In the case of Nicaragua the study incorporated two dummy variables, one capturing the effects from the period of hyper inflation covering 1985-1994 and the other covering the Sandinista Regime. Dummies turned out to be insignificant and were removed from the regressions. The series for both Nicaragua and Costa Rica do not appear to suffer from spurious regressions, because the Durban-Watson (DW) statistic was greater than the $R$-squared for both Nicaragua $(R$-squared $=0.9042 ; \mathrm{DW}=1.852)$ and Costa Rica $(R$-squared $=0.9613$ and DW $=2.120)$. The residuals stemming from poverty as the dependent variables are stationary at levels, confirming that the series in both cases of Nicaragua and Costa Rica are cointegrated.

The second step consisted in including the lag of the residuals from the initial regression, which combines the long-run information with a short-run adjustment mechanism. Table 7 reports the results. The case of Nicaragua reveals that the error correction coefficient and the lag of tourism receipts are both significant, indicating that error correcting long-term equilibrium behaviour occurs. However, a change in the incidence of tourism in the total economy does not seem to have any statistically significant contemporaneous effect on poverty reduction. A one point increase in tourism receipts reduces the headcount by 0.045 points over future time periods; in one time period the poverty head is reduced by 0.09 . We estimated the elasticity of poverty induced by tourism multiplying the tourism coefficient calculated by the long-run regression times the tourism share of GDP. Hence, the growth poverty elasticity is 1.23. This means that a $1 \%$ increase in international tourism receipts is associated with a $1.23 \%$ decrease in the poverty rate (proportion of people living on less than a US\$1 per day).

Similar instantaneous effects are revealed in the case of Costa Rica where the error correction for the estimated growth equation is negative with the speed of adjustment at $14 \%(t=-2.46)$ annually, but tourism does not entertain any contemporaneous statistically significant effects $(t=-0.74)$. Tourism seems to have a different trajectory in the case of Nicaragua compared to Costa Rica.

Table 7. Econometric results: variables explaining percentage change, tourism-poverty.

\begin{tabular}{lcc}
\hline & \multicolumn{2}{c}{ Error correction model } \\
& Nicaragua & Costa Rica \\
Constant & 0.381 & 0.124 \\
$\Delta$ Tourism/GDP [-1] & $-0.654(-1.42)$ & $0.099(1.18)$ \\
$\Delta$ Tourism/GDP [-1] & $-0.382(-2.09)^{*}$ & $-0.013(-0.74)$ \\
$\Delta$ Experts/GDP [-1] & $0.062(0.66)$ & $0.092(1.05)$ \\
Error correction term [-1] & $-0.188(-2.79)^{*}$ & $-0.139(-2.46)^{*}$ \\
$R$-square & 0.3452 & 0.3966 \\
$F$-statistics & $3.16^{*}$ & $3.94^{*}$ \\
Breusch-Godfrey & $0.148(p=0.7002)$ & $1.053(p=0.3047)$ \\
Breusch-Pagan & $0.00(p=9691)$ & $0.15(p=0.6944)$ \\
\hline
\end{tabular}

Note: $*<5 \%$. 
Table 8. Granger causality tests.

\begin{tabular}{|c|c|c|c|c|c|c|}
\hline \multirow[t]{2}{*}{ Hypothesis } & \multicolumn{2}{|c|}{ Optimal lag } & \multicolumn{2}{|c|}{$F$-statistics } & \multicolumn{2}{|c|}{ Conclusion } \\
\hline & Nicaragua & Costa Rica & Nicaragua & Costa Rica & Nicaragua & Costa Rica \\
\hline $\begin{array}{l}\text { Null: Tourism } \\
\text { (T) does not } \\
\text { Granger cause } \\
\text { poverty (P) } \\
\text { (tourists/GDP) }\end{array}$ & 3 & 1 & 6.2463 & $33.316^{*}$ & $\mathrm{~T} \neq \mathrm{P}$ & $\mathrm{T} \rightarrow \mathrm{P}$ \\
\hline $\begin{array}{l}\text { Null: Tourism } \\
\text { does not } \\
\text { Granger cause } \\
\text { poverty (tourist } \\
\text { receipts) }\end{array}$ & 3 & 1 & $9.4981^{*}$ & $23.597^{*}$ & $\mathrm{~T} \rightarrow \mathrm{P}$ & $\mathrm{T}^{\prime} \rightarrow \mathrm{P}$ \\
\hline $\begin{array}{l}\text { Null: Poverty } \\
\text { (tourism/GDP) } \\
\text { does not } \\
\text { Granger cause } \\
\text { tourism }\end{array}$ & 3 & 3 & 0.309 & 7.7065 & $\mathrm{~T} \neq \mathrm{P}$ & $\mathrm{P} \neq \mathrm{T}$ \\
\hline $\begin{array}{l}\text { Poverty } \\
\text { (tourists } \\
\text { receipts) does } \\
\text { not Granger } \\
\text { cause tourism }\end{array}$ & 3 & 3 & 0.159 & $15.396^{*}$ & $\mathrm{~T} \neq \mathrm{P}$ & $\mathrm{P} \rightarrow \mathrm{T}$ \\
\hline
\end{tabular}

Note: *Hypothesis at the 0.05 level.

Tourism entertains both a contemporaneous effect as well as a long impact on poverty reduction (the coefficient $=-0.147 ; t=-2.72$ ). While tourism does not have a contemporaneous effect in the case of Costa Rica, it does have a long-term effect, albeit a positive one. The long-term coefficient was 0.24 $(t=1.78)$. This implies that tourism does not seem to benefit the poor in the long run.

The study applied the necessary diagnostic tests such as the Durbin-Watson and the Breusch-Godfrey LM test for autocorrelation. In addition, a BreuschPagan/Cook-Weisberg test for heteroskedasticity was conducted. All the results are reported in Table 7 . Finally the study investigated the causal relationship between tourism and poverty reduction in the case of Nicaragua. Table 8 reports the results, indicating in the case of Nicaragua that the relationship between tourism spending and poverty reduction runs from tourism spending to poverty reduction. Unlike Nicaragua, the case of Costa Rica reveals a bidirectional link between tourism and poverty. Both further specialization in tourism as well as tourism receipts appear to Granger cause poverty, while poverty seems to Granger cause tourism only as it pertains to tourism receipts. Because the relationship between tourism and poverty is positive as revealed by the results, the implication is that quality offerings and service have a long-run impact on poverty by seemingly excluding the poor from the benefits of tourism. 


\section{Conclusion}

The study assessed countering a critical question whether tourism matters for absolute poverty. The study entertained three propositions: (i) tourism matters for the poor; (ii) tourism does not have systematic effects on the poor; and (iii) tourism development matters most for the poor at lower levels of economic development.

The first proposition suggests that tourism is an important determinant of poverty reduction under certain conditions. Three conditions seem relevant, according to this study: (i) a high incidence of extreme poverty; (ii) lower level of economic development; and (iii) a tourism sector in its developing stage. The level of extreme poverty in Nicaragua is $45 \%$ with a rural sector plagued by poverty and lack of economic and social opportunities. Nicaragua's GDP per capita is the second lowest in the Western Hemisphere after Haiti, and it has the second lowest human development index, again after Haiti. Tourism's contribution to Nicaragua's GDP was $6.4 \%$ on average between 2003 and 2008, while its contribution to employment was $5.2 \%$. The contribution of tourism in Costa Rica, on the other hand, was, respectively, $14.3 \%$ and $13.9 \%$ in terms of GDP and employment (Cañada, 2010).

Indeed, the case of Nicaragua suggests that a $1 \%$ increase in tourism receipts reduces the poverty index by 1.23 points. International tourism receipts increased by $11 \%$ in 2009 compared to 2008, according to reports from the World Bank. This increase means a decrease of 5.68 points in the poverty index, ceteris paribus. Tourism is relevant in Nicaragua where tourism spending affects poverty reduction. Increased tourism spending means heightened opportunities for employment for the poor. A report by ECLAC (2007) suggested that job creation entertains the most potential for tourism in Nicaragua in its search to defeat poverty. Besides the amount of jobs created, tourism seems to provide better quality jobs in terms of providing healthier, safer and more pleasant working conditions than other economic sectors in Nicaragua. Lengefeld and Beyer (2006) found while the hotel sector may entertain lower wages than, for example, the sugar industry, hotel employees have permanent contracts and have better fringe benefits, such as a bonus and paid leave.

Rivera et al (2007) also found that international tourism in Nicaragua has a larger impact on the gross domestic product than any other sector in the economy. They disaggregated the labour force into four different income categories and detected the ability of tourism to spread more income to the poor compared to the other economic sectors. Hara (2008) also found that those with the lesser income in the labour market will benefit the most in terms of receiving additional incomes from tourism spending compared to the other economic sectors in the economy. Finally, rising incomes for the individuals and households mean the government would receive higher taxes which would increase the government's capacity to invest in infrastructure, health, education and other services relevant for the poor.

Tourism receipts are more important to the poor in Nicaragua than the size of tourism in the total economic structure. The reason may be that the informal sector of the economy in Nicaragua is strong, limiting the effects of the formal economy on the poor. For example, the Central Bank of Nicaragua (2003) estimated that the informal sector in the country accounted for $41 \%$ of the total 
economy. In Nicaragua self-employment is dominant and there appear to be many unpaid individuals working in family business (Gutierrez et al, 2008). Tourism seems to be the key to job generation in the informal sector as well as in providing vending opportunities for poor households.

The second proposition of the study is that tourism does not have systematic effects on the poor. In Costa Rica, which enjoys a higher level of economic development than Nicaragua, tourism does not seem to matter for the poor. Unlike Nicaragua, job creation in Costa Rica is not the main catalysts against poverty. One additional international tourist to Costa Rica generates fewer jobs, which implies some diminishing returns (ECLAC, 2007). Pay in tourism jobs is comparatively lower than the average pay in the country (ECLAC, 2007), and jobs seem affected by seasonality (Ferguson, 2010).

Tourism development in Costa Rica provokes unintended consequences: the poor are excluded from job opportunities and displaced from the job market in the hospitality industry. Higher educated Costa Ricans, foreigners or immigrants from Nicaragua fill job openings. For example, the poor and local people did not get most direct and indirect jobs in tourism related business in the Guanacaste area; instead employees from other regions of the country and foreigners got these jobs (Honey et al, 2010). How tourism revenues are shared has a strong impact on poverty reduction in poor households because poor households spend a larger part of their income in food, health and education.

According to Gindling (2009), the levels of inequality in Costa Rica have increased since the 1990s and poverty rates have stagnated despite economic growth. At the same time opportunities for the poor in Costa Rica dwindled, and increased crime assailed the poor. Crime is taxing vulnerable population segments the most by increasing health and other costs significantly (AcevedoArreguin, 2008). Tourism development in Costa Rica appears unable to further help the fate of the poor. Thus, direct benefits from tourism to the poor seem limited. The effects of tourism spending affecting the poor have reached a threshold beyond which the poor does not gain any benefits.

Pro-poor growth means that tourism benefits the poor (Mitchell and Ashley, 2010). Tourism development appears to provide benefits to the poor in Nicaragua and thus can be labelled as being pro-poor. The case of Costa Rica, on the other hand, does not pass the pro-poor test, as indicated previously. Tourism development matters most for the poor at lower levels of economic development. The policy implication seems clear: where the condition exists of a large presence of poverty (Nicaragua) promoting tourism development seems to be the proper pathway. The policy intervention should consist of three actions. First, government should align economic incentives with social costs and benefits to stimulate investment in the tourism sector (for example, hotels, restaurants and transportation). In particular, government intervention should tackle the informal economy due to its potential to engage the poor in tourism. For example, the government should create an enabling environment for enterprise and eliminate unwarranted and onerous regulations and lack of access to credit in Nicaragua.

Second, the government should aggressively market the country to increase international tourism demand and spending. The objectives of these policy actions should be creating more jobs and generating larger indirect economic effects (linkages). Linkages seem to benefit poor households more than direct 
effects and it seems easier to improve linkages than reduce leakages in the economy (Lejarraga and Walkenhorst, 2007). And third, tourism growth more likely will generate higher tax revenues that should be used to provide more infrastructure. Improved infrastructure could reduce transport costs that could help poor households.

Conversely, if a condition exists of a relatively small amount of poor people as in the case of Costa Rica, creating jobs or raising private incomes would not be enough to lessen poverty. The case of Costa Rica implies that when job generation signals diminishing returns, tourism development may have only limited effects on the poor. A policy based only on promotion of tourism demand would not help the poor. Effects of tourism development to help the poor can only be capitalized through budgetary expenditures. Policy actions should be focused specifically on poor households, including training, encouragement of entrepreneurship and development of firms and product development in particular for small firms.

The orientation on human resource development is not an easy assignment and depends on the effectiveness of budgetary targeting and delivery to produce the highest marginal impact. Costa Rica is experiencing challenges adversely affecting its effectiveness in delivering high impact social programmes. For example, Costa Rica is confronting serious challenges in the delivery of its secondary school programme. Failure, grade repetition and dropouts rates are alarming, costing the country close to $0.5 \%$ of the GDP each year, according to the World Bank (2009). Chant (2009) claims that despite extensive programs to reduce poverty among women in Costa Rica, the results have been deprived. Poverty among women has increased over time, despite significant reduction in poverty in Costa Rica. The study of van der Duim and Caalders (2008) found meagre results of pro-poor projects in Costa Rica because of the difficulty in aligning small-scale enterprises with Dutch tourism chains. The study identified lack of managerial, administrative and basic business and communications skills as the main obstacles in forging sound business relationship. In the case of Costa Rica, providing basic business education to small farmers, street vendors, shopkeepers and potential entrepreneurs can lift them out of poverty. The marginal impact on the poor hinges on the quality of governance in how to manage more complex issues regarding human resource development and in aligning the right incentives with the private sector to create partnership to mobilize resources supporting the value chain that would benefit the poor (Croes, 2012).

The limitation of this study may be that, by equating poverty to income, the study, perhaps unwillingly, created some evidence that tourism spending and economic growth could lessen poverty only if we consider averages. The heterogeneity in country circumstances plays a large role here. Had the study disaggregated the numbers and, for example, examined different regions, income groups or gender within a country, then, invariably, the study would have confronted issues of inequality. Poverty relates to the increase in and distribution of income. This latter issue seems timelier for Costa Rica, which has substantially reduced the presence of extreme poverty. Inequality has become a barrier to better opportunities for an expansion of capabilities and human development in Costa Rica (UNDP, 2010). A caveat regarding the use of the error correction model should be made. Because of the small size of the sample, 
the study could have incurred the potential pre-testing bias caused by the low power of the unit root and cointegration tests.

Future research should investigate whether tourism spending would spur a pattern of inequalities in the form of an inverted U-pattern, as argued by Kuznets (1955) (initially an increase in equality, then turning into a decrease in equality as the income level increases). Or is tourism spending simply a continuity of the same whether growth is going to the rich who already have high incomes or whether growth is going to those in need? Assessing the effects of tourism on economic growth and poverty relief is more than academic interest. Governments, political and social actors should apprise themselves of a thorough assessment of this study's results to devise or propose policies that complement tourism spending as a development strategy for poverty relief. Further, these actors could be in position to account for imbalance in the distribution of the monies that tourism could afford.

\section{References}

Acevedo-Arreguin, L.A. (2008), 'Spatial temporal statistical modeling of crime data: the kernel convolution approach', Master's thesis, University of California Santa Cruz.

Arvin, B., and Barillas, F. (2002), 'Foreign aid, poverty reduction and democracy', Applied Economics, Vol 34, No 1, pp 2151-2156.

Balaguer, J., and Cantavella-Jorda, M. (2002), 'Tourism as a long-run economic growth factor: the Spanish case', Applied Economics, Vol 34, No 1, pp 877-884.

Banerjee, A.V., and Duflo, E. (2007), 'The economic lives of the poor', Journal of Economic Perspectives, Vol 21, No 1, pp 141-167.

Belisle, F.J., and Hoy, D.R. (1980), 'The perceived impact of tourism by residents a case study in Santa Marta, Colombia', Annals of Tourism Research, Vol 7, No 1, pp 83-101.

Blake, A., Arbache, J., Sinclair, M., and Teles, V. (2008), 'Tourism and poverty relief', Annals of Tourism Research, Vol 35, No 1, pp 106-127.

Bourguignon, F. (2006), 'From income to endowments: the difficult task of expanding the income poverty paradigm', in Grusky, B., and Kanbur, D., eds, Poverty and Inequality, Stanford University Press, Stanford, CA.

Brau, R., Lanza, A., and Pigliaru, F. (2003), 'How fast are the tourism countries growing? The crosscountry evidence' (September 2003), FEEM Working Paper No 85.2003 (http://ssrn.com/abstract $=453340$ or http://dx.doi.org/10.2139/ssrn.453340, access 10 February 2014).

Brau, R., Lanza, A., and Pigliaru, F. (2005), 'An investigation on the growth performance of small tourism countries', in Lanza, A., Markandya, A., and Pigliaru, F., eds, The Economics of Tourism and Sustainable Development, Edward Elgar, Cheltenham, pp 8-29.

Cañada, E. (2010), Turismo y Conflictos Socio-Ambientales en Centroamerica, Editorial Enlace, Managua.

Capo, J., Font, A., and Nadal, J. (2007), 'Dutch disease in tourism economies: evidence from the Balearics and the Canary islands', Journal of Sustainable Tourism, Vol 15, No 6, pp 615-627.

Central Bank of Nicaragua (2003), Economic Indicators, Banco Central de Nicaragua, Managua.

Chant, S. (2009), 'The "feminization of poverty" in Costa Rica: to what extent a conundrum?', Bulletin of Latin American Research, Vol 28, No 1, pp 19-43.

Chen, S., and Ravallion, M. (2001), 'How did the world's poor fare in the 1990s', Review of Income and Wealth, Vol 47, No 3, pp 283-300.

Clancy, M. (1999), 'Tourism and development: evidence from Mexico', Annals of Tourism Research, Vol 26, No 1, pp 1-20.

Croes, R. (2012), 'Assessing tourism development from Sen's capability approach', Journal of Travel Research, Vol 51, No 5, pp 542-554.

Croes, R., and Vanegas, M., snr (2008), 'Tourism and poverty alleviation: a co-integration analysis', Journal of Travel Research, Vol 47, No 1, pp 94-103.

Deaton, A. (2002), 'Is world poverty falling?', Finance and Development, Vol 39, No 2, pp 4-7.

De Soto, H. (2000), The Mystery of Capital, Basic Books, New York.

Dickey, D.A., and Fuller, W.A. (1979), 'Distribution of the estimators for autoreggresive: time series with a unit root', Journal of the American Statistical Association, Vol 74, No 366, pp 427-431. 
Dickey, D.A., and Fuller, W.A., (1981), 'Likelihood ratio statistics for autoregression: time series with a unit root', Econometrica, Vol 49, No 4, pp 1057-1072.

Dritsakis, N. (2004), 'Tourism as a long-run economic growth factor: an empirical investigation for Greece using causality analysis', Tourism Economics, Vol 10, No 3, pp 305-316.

Durbarry, R. (2004), 'Tourism and economic growth: the case of Mauritius', Tourism Economics, Vol 10, No 4, pp 389-401.

Dwyer, L., Forsyth, P., and Spurr, R. (2003), 'Inter-industry effects of tourism growth: implications for destination managers', Tourism Economics, Vol 9, No 2, pp 117-132.

Easterly, W. (2002), The Elusive Quest for Growth, MIT Press, Cambridge, MA.

ECLAC (2007), Panorama social 2006, ECLAC, Santiago de Chile.

Engle, R.F., and Granger, C. (1987), 'Co-integration and error correction: representation, estimation, and testing', Econometrica, Vol 55, No 2, pp 251-276.

Eugenio-Martin, J., Morales, N., and Scarpa, R. (2004), 'Tourism and economic growth in Latin American countries: a panel data approach', FEEM Working Paper No 26, Fondazione Eni Enrico Mattei, Milan.

Ferguson, C. (2010), 'Principles of transitional care for young people with longstanding continence problems', Nursing Times, Vol 106, p 47.

George A.L. (1979), 'Case studies and theory development: the method of structured, focused comparison', in Lauren, G., ed, Diplomacy: New Approaches in History, Theory and Policy, New Approaches, New York.

Ghali, M. (1976), 'Tourism and economic growth: an empirical study', Economic Development and Cultural Change, Vol 24, No 3, pp 527-538.

Gindling, T. (2009), 'South-south migration: the impact of Nicaraguan immigrants on earnings, ineqaulity and poverty in Costa Rica', World Development, Vol 37, No 1, pp 116-126.

Gutierrez, C., Paci, P., and Ranzani, M. (2008), Making Work Pay in Nicaragua. Employment, Growth, and Poverty Reduction, World Bank, Washington, DC.

Hara, T. (2008), Quantitative Tourism Industry Analysis: Introduction to Input-Output, Social Accounting Matrix Modeling and Tourism Satellite Accounts, Elservier, Burlington, MA.

Hawkins, D., and Mann, S. (2007), 'The world bank's role in tourism development', Annals of Tourism Research, Vol 34, No 2, pp 348-363.

Hazari, B., and Sgro, P. (1995), 'Tourism and growth in a dynamic model of trade', The Journal of International Trade and Economic Development, Vol 4, No 2, pp 253-256.

Hazari, B., Nowak, J., Sahli, M., and Zdravevski, D. (2003), 'Tourism and regional immizerization', Pacific Economic Review, Vol 8, No 3, pp 269-278.

Honey, M., Vargas, E., and Durham, W. (2010), 'Impact of tourism related development on the Pacific coast of Costa Rica', Center for Responsible Travel, Stanford University (http:// www.responsibletravel.org/resources/documents/Coastal-tourism-documents/Summary\%20Report/ Summary_Report__Impact_Tourism_Related_Development_Pacific_Coast_Costa_Rica.pdf, accessed 4 July 2012).

Johansen, S., and Juselius, K. (1990), 'Maximum likelihood estimation and inference on cointegration: with the application to the demand of money', Oxford Bulletin of Economics and Statistics, Vol 52, pp 169-210.

Kaldor, N. (1964), 'International trade and economic development', The Journal of Modern African Studies, Vol 2, No 4, pp 491-551.

Kaldor, N. (1970), 'The case for regional policies', Scottish Journal of Political Economy, Vol 17, No 3, pp 337-348.

Katircioglu, S. (2009), 'Revisiting the tourism-led-growth hypothesis for Turkey using the bounds test and the Johansen approach for cointegration', Tourism Management, Vol 30, No 1, pp 17-20.

Kim, H., Chen, M., and Jang, S. (2006), 'Tourism expansion and economic development: the case of Taiwan', Tourism Management, Vol 27, pp 925-933.

Kuznets, S. (1955), 'Economic growth and income inequality', The American Economic Review, Vol 45, No 1 , pp $1-28$.

Lanza, A., and Pigliaru, F. (2000), 'Why are tourism countries small and fast growing?', in Fossati, A., and Panella, G. eds, Tourism and Sustainable Economic Development, Kluwer, Dordrecht, pp 5769.

Lejarraga, I., and Walkenhorst, P. (2007), Diversification by Deepening Linkages with Tourism, World Bank, Washington, DC (http://siteresources.worldbank.org/INTEXPCOMNET/Resources/ Lejárraga,_Diversification_by_Deepening_Linkages_with_Tourism.pdf).

Lengefeld, K., and Beyer, M. (2006), 'CSR beyond charity: how the core business of all-inclusive 
contributes to poverty alleviation and local development in the Caribbean and Central America', paper presented at the VIth Corporate Social Responsibility for Sustainable Tourism, 13-16 June, University of Girona, Spain.

Lijphart, A. (1975), 'The comparable-cases strategy in comparative research', Comparative Political Studies, Vol 8, pp 158-177.

Lucas, R. (1988), 'On the mechanics of economic development', Journal of Monetary Economics, Vol 22, pp 3-42.

Mak, J. (2004), Tourism and the Economy: Understanding the Economics of Tourism, University of Hawaii Press, Honolulu, HI

Mitchell, J., and Ashley, C. (2010), Tourism and Poverty Reduction. Pathways to Prosperity, Earthscan, London.

Modeste, N.C. (1995), 'The impact of growth in the tourism sector on economic development: the experience of selected Caribbean countries', Economia Internazionale, Vol 48, No 3, pp 375-385.

Mukherjee, C., White, H., and Wuyts, M. (1998), Econometrics and Data Analysis for Developing Countries, Routledge, Abingdon.

Narayan, P. (2004), 'Tourism demand modeling: some issues regarding unit roots, cointegration and diagnostic tests', International Journal of Tourism Research, Vol 5, No 5, pp 369-380.

Nowak, J.J., and Sahli, M. (2007), 'Coastal tourism and Dutch disease in a small island economy', Tourism Economics, Vol 13, No 1, pp 49-65.

Oh, C.O. (2005), 'The contribution of tourism development to economic growth in the Korean economy', Tourism Management, Vol 26, No 1, pp 39-44.

Phillips, P.C.B., and Perron, P. (1988), 'Testing for a unit root in time series regression', Biometrika, Vol 75, No 2, pp 335-346.

Ravallion, M. (2001), 'Growth, inequality and poverty: looking beyond the averages', World Development, Vol 29, No 11, pp 1803-1815.

Rivera, M., Hara, T., and Croes, R. (2007), 'Quantitative modeling of poverty alleviation through tourism in Nicaragua', 54th North American Regional Science Council (NARSC) Conference, Regional Science Association International, Savannah, GA.

Sachs, J.D. (2005), Investing in Development: A Practical Plan to Achieve the Millennium Development Goals: Overview, UNDP/Communications Development, New York.

Sandler, T. (2001), Economic Concepts for the Social Sciences, Cambridge University Press, Cambridge.

Sequeira, T., and Nunes, P (2008), 'Does tourism influence economic growth? A dynamic panel data approach', Applied Economics, Vol 40, No 18, pp 2431-2441.

Shan, J., and Wilson, K. (2001), 'Causality between trade and tourism: empirical evidence from China', Applied Economics Letters, Vol 8, No 4, pp 239-283.

Sinclair, M. (1998), 'Tourism and economic development: a survey', Journal of Development Studies, Vol 34, No 5, pp 1-51.

Sinclair, M.T., and Stabler, M. (1997), The Economics of Tourism, Routledge, London,

Song, H., Witt, S.F., and Li, G. (2009), The Advanced Econometrics of Tourism Demand, Routledge, New York.

Sugiyarto, G. (2007), Poverty Impact Analysis: Selected Tools and Applications, ADB, Manila.

UNICEF (2008), The State of the World's Children 2009, United Nations Children's Fund, New York.

United Nations Development Program (UNDP) (2010), Informe Regional Sobre Desarrollo Humano Para America Latina y el Caribe 2010, United Nations Development Program, New York.

Van Der Duim, V.R., and Caalders, J. (2008), 'Tourism chains and pro-poor tourism development: an actor-network analysis of a pilot project in Costa Rica', Current Issues in Tourism, Vol 11, No 2, pp 109-125.

West, G.R. (1993), 'Economic significance of tourism in Queensland', Annals of Tourism Research, Vol 20, No 3, pp 490-504.

World Bank (2009), Costa Rica, Competitiveness Diagnostic and Recommendations, World Bank, Washington, DC

WTO (World Tourism Organization) (2002), Tourism and Poverty Alleviation, WTO, Madrid.

Zhou, D., Yanagida, J.F., Chakrovorty, U., and Leung, P. (1997), 'Estimating economic impacts from tourism', Annals of Tourism Research, Vol 24, No 1, pp 76-89.

Yin, R.K. (1994), Case Study Research: Design and Methods, SAGE Publications, Newbury Park, CA. 